Pinardi: Analisis Miskonsepsi Siswa pada Materi Operasi Hitung Campuran di SDN 8 Pahandut Palangka Raya

\author{
Analisis Miskonsepsi Siswa pada Materi Operasi Hitung Campuran \\ di SDN 8 Pahandut Palangka Raya \\ Janu Pinardi ${ }^{1}$, Abdul Rahman Azahari ${ }^{2}$, Bejo Basuki ${ }^{3}$ \\ Email: janupinardi123@gmail.com ; rahman.azahari63@gmail.com \\ bejobasuki66@gmail.com
}

doi: https://doi.org/10.52850/jpn.v22i2.3843

\begin{abstract}
Abstrak
Tujuan penelitian ini, untuk mengetahui miskonsepsi operasi hitung campuran dan penyebabnya. Penelitian dilaksanakan dengan metode deskriptif kualitatif menggunakan studi kasus. Subjek penelitian adalah tiga orang siswa kelas V SDN-8 Pahandut Palangka Raya. Prosedur pengolahan data dengan menganalisis hasil tes dan wawancara serta membuat tabulasi dan deskripsi data. Hasil penelitian menunjukkan bahwa, pertama, miskonsepsi terjemahan disebabkan kurangnya pemahaman terhadap petunjuk pengerjaan dan mengubah bahasa dalam soal ke dalam bahasa matematika yang benar. Kedua, miskonsepsi konsep disebabkan siswa tidak memahami konsep atau definisi operasi hitung dasar pada materi operasi hitung campuran. Ketiga, miskonsepsi strategi disebabkan siswa kurang tepat menentukan prosedur dan sifat, operasi hitung dengan benar. Keempat, miskonsepsi sistematik disebabkan siswa kurang lengkap dan tepat menuliskan langkah-langkah menyelesaikan soal. Kelima, miskonsepsi tanda dimana siswa tidak tahu operasi hitung mana yang harus dikerjakan terlebih dahulu, dan lemah dan kurang teliti mengoperasi pengurangan bilangan negatif. Keenam, miskonsepsi berhitung sebagai akibat siswa salah mengoperasikan hitung campuran.
\end{abstract}

Kata Kunci: Konsep, miskonsepsi, operasi hitung campuran, strategi, sistematik, tanda, terjemahan

\title{
The Students' Misconception on Mixed Arithmetic Operations in SDN 8 Pahandut Palangka Raya
}

\begin{abstract}
The purpose of the study was to determine the misconceptions of mixed arithmetic operations and their causes. The research was carried out with a qualitative descriptive method using case studies. The subjects were three students of fifth grade SDN-8 Pahandut Palangka Raya. Data procedures by analyzing the results of tests, interviews, tabulations and data descriptions.
\end{abstract}

\footnotetext{
${ }^{1}$ Prodi Pendidikan Profesi Guru FKIP UPR Jl. H. Timang Palangka Raya

${ }^{2}$ Prodi Pendidikan Profesi Guru FKIP UPR Jl. H. Timang Palangka Raya

${ }^{3}$ Prodi Pendidikan Profesi Guru FKIP UPR Jl. H. Timang Palangka Raya
} 
The results show that, first, the translation misconception was caused by a lack of understanding of the working instructions and changing the language in the problem into the correct mathematical language. Second, the conceptual misconception caused by students not understanding the concept or definition of basic arithmetic operations on mixed arithmetic operations material. Third, the strategic misconception is caused by students not correctly determining the procedures and properties of arithmetic operations. Fourth, systematic misconception caused of students incomplete and correctly write down the steps to solve the problem. Fifth, sign misconception where students do not know which arithmetic operations to do first and are weak and less thorough in operating the subtraction of negative numbers. Sixth, the counting misconception as a result of students miss-operating with mixed arithmetic.

Keywords: conceptual, counting, strategic, systematic, sign, translation, misconception, mixed operations

Proses pembelajaran yang diterapkan pada mata pelajaran matematika lebih menekankan pada konsep awal yang sudah diketahui oleh siswa, selanjutnya dapat ditingkatkan ke proses yang lebih tinggi sebagai pembentukan pengetahuan yang baru. Konsep awal yang dimiliki oleh siswa kadang-kadang tidak sesuai dengan konsep sebenarnya. Konsep yang dibentuk oleh masing-masing individu (siswa) berdasarkan pengertiannya sendiri, akibatnya sering terjadi suatu kesalahan konsep atau miskonsepsi. Miskonsepsi sering ditemukan pada mata pelajaran matematika, karena materi saling berkaitan. Salah satu materi yang harus dipelajari dengan kompetensi tertentu sesuai dengan tingkat kemampuan siswa, adalah operasi hitung campuran.

Memahami konsep hitung campuran merupakan dasar untuk dapat memahami permasalahan terapan dalam kehidupan sehari-hari. Apabila siswa mengalami miskonsepsi pada materi sebelumnya maka dapat diduga akan berakibat pada pengetahuan yang baru yang akan diperoleh siswa. Hasil penelitian yang relevan yang terkait miskonsepsi pada materi lain, Lestari (2017) menyatakan bentuk-bentuk miskonsepsi terjadi pada: miskonsepsi terjemahan, miskonsepsi konsep, miskonsepsi strategi, miskonsepsi sistematik, miskonsepsi tanda, dan miskonsepsi berhitung. Adapun faktor yang menyebabkan siswa mengalami miskonsepsi tersebut diantaranya: miskonsepsi terjemahan yaitu kurangnya pemahaman penulisan yang diubah ke dalam model matematika, miskonsepsi konsep yaitu dikarenakan tidak paham definisi, miskonsepsi strategi yaitu menggunakan rumus yang tidak tepat, 
miskonsepsi sistematik yaitu penggunaan sifat dan teorema atau rumus yang masih kurang tepat, miskonsepsi tanda yaitu karena lupa, miskonsepsi berhitung yaitu akibat terburu-buru.

Berdasarkan permasalahan yang dikemukakan di atas maka tujuan dalam penelitian ini adalah untuk mengetahui: 1) bentuk-bentuk miskonsepsi siswa, dan 2) penyebab terjadinya miskonsepsi siswa di Sekolah Dasar.

Pemahaman konsep merupakan aspek penting dalam pembelajaran, karena dengan konsep siswa dapat mengembangkan kemampuannya dalam setiap materi pelajaran. Menurut Sardiman (2014: 42), "Pemahaman atau comprehension dapat diartikan menguasai sesuatu dengan pikiran". Menurut Hamalik (2014: 162), "Konsep adalah suatu kelas atau kategori stimuli yang memiliki ciri-ciri umum”. Sedangkan menurut Depdiknas (Kesumawati, 2008: 2), "Konsep diartikan sebagai ide abstrak yang dapat digunakan untuk menggolongkan sekumpulan objek". Jadi dapat disimpulkan bahwa pemahaman konsep merupakan tahap yang paling mendasar yang harus dicapai siswa agar dapat lebih mudah untuk melanjutkan tingkat pemahaman selanjutnya dan bagian penting dalam pembelajaran matematika.

Pemahaman konsep matematika menurut Depdiknas (Kesumawati, 2008: 3), "Pemahaman konsep merupakan salah satu kecakapan atau kemahiran matematika yang diharapkan dapat tercapai dalam belajar matematika yaitu dengan menunjukkan pemahaman konsep matematika yang dipelajarinya, menjelaskan keterkaitan antar konsep dan mengaplikasikan konsep atau algoritma secara luwes, akurat, efisien, dan tepat dalam pemecahan masalah". Dengan begitu dapat dipahami bahwa pemahaman konsep matematika merupakan kompetensi atau kemampuan yang ditunjukkan siswa dalam menemukan dan mejelaskan, menterjemahkan, menafsirkan, dan menyimpulkan suatu konsep matematika berdasarkan pembentukan pengetahuan sendiri, bukan sekedar menghafal.

Pada saat belajar, siswa menerima konsep baru yang siswa miliki melalui penalaran, pengetahuan, dan pemikiran. Tetapi kebanyakan konsepsi-konsepsi yang siswa miliki terkadang tidak sesuai dengan konsepsi para ilmuwan atau para ahli. Konsepsi-konsepsi yang tidak sesuai dengan konsepsi para ilmuwan atau para ahli inilah disebut miskonsepsi.

Menurut Suparno (2013: 8), "Miskonsepsi adalah suatu konsep yang tidak sesuai dengan konsep yang diakui oleh para ahli”. Menurut Fowler (Suparno, 2013: 5), "Miskonsepsi sebagai pengertian yang tidak akurat akan konsep, penggunaan konsep yang salah, klasifikasi contoh-contoh yang salah, kekacauan konsep-konsep yang berbeda, dan 
hubungan hirarkis konsep-konsep yang tidak benar”. Leinhardt, dkk (Herutomo dan Saputro, 2014: 2), "Mendefinisikan miskonsepsi sebagai pemahaman yang salah dalam pengetahuan siswa yang terjadi secara berulang dan eksplisit". Dalam pembelajaran matematika, miskonsepsi dapat diartikan sebagai kesalahan pemahaman konsep yang dilakukan dalam memahami konsep-konsep dalam matematika, serta kesalahan konsep dalam menyelesaikan soal matematika.

Adapun macam bentuk miskonsepsi yang telah banyak dikemukakan para ahli. Menurut Cox (Setiawan, 2015: 9) bahwa miskonsepsi ditinjau dari sifatnya dikelompokkan menjadi empat bagian, yaitu: “1) miskonsepsi yang sistematis (systematic error), yaitu kesalahan yang terjadi jika siswa membuat kesalahan dengan pola yang sama pada sekurangkurangnya tiga soal dari lima soal yang diberikan; 2) miskonsepsi yang random (random error) adalah kesalahan yang terjadi jika siswa membuat kesalahan dengan pola yang berbeda pada sekurang-kurangnya tiga soal dari lima soal yang diberikan; 3) miskonsepsi yang diakibatkan dari kecerobohan adalah kesalahan yang terjadi jika siswa hanya membuat dua kesalahan dari lima soal yang diberikan;(4) miskonsepsi yang tidak dapat dimasukkan dalam salah satu tipe di atas, misalnya lembar data yang tidak lengkap”.

Menurut Sriati (Setiawan, 2015: 9) miskonsepsi yang berasal dari dalam mengerjakan soal matematika secara khusus, yaitu: “1) miskonsepsi terjemahan, adalah kesalahan mengubah informasi keungkapan matematika atau kesalahan dalam memberi makna suatu ungkapan matematika; 2) miskonsepsi konsep, adalah kesalahan memahami gagasan abstrak; 3) miskonsepsi strategi, adalah kesalahan yang terjadi jika siswa memilih jalan yang tidak tepat yang mengarah ke jalan buntu; 4) miskonsepsi sistematik, adalah kesalahan yang berkenaan dengan urutan pengerjaan; 5) miskonsepsi tanda, adalah kesalahan dalam memberikan atau menulis tanda, operasi atau notasi; 6) miskonsepsi berhitung, adalah kesalahan menghitung dalam operasi matematika seperti menjumlah, mengurangkan, mengalikan, dan membagi".

Berdasarkan uraian di atas, miskonsepsi dapat diartikan sebagai suatu konsepsi atau pemahaman seseorang yang tidak sesuai dengan pemahaman para ilmuan atau para ahli. Dengan begitu miskonsepsi matematika dapat diartikan sebagai kesalahan pemahaman konsep yang dilakukan dalam memahami konsep-konsep dalam matematika, serta kesalahan konsep dalam menyelesaikan soal matematika. Pada penelitian ini, diambil konsep integral 90 
tentu dengan bentuk miskonsepsi yang dipakai yaitu miskonsepsi terjemahan, miskonsepi konsep, miskonsepsi strategi, miskonsepsi sistematik, miskonsepsi tanda, dan miskonsepsi berhitung, dengan indikator-indikator berikut.

\section{Metode Penelitian}

Metode penelitian yang digunakan adalah deskriptif kualitatif, menggunakan studi kasus. Subjek penelitian adalah siswa kelas V SDN-8 Pahandut Palangka Raya. Selanjutnya dipilih 3 siswa berdasarkan kriteria yang sesuai dengan indikator yang diinginkan untuk dilakukan wawancara dalam upaya mengetahui penyebab siswa mengalami miskonsepsi. Pengumpulan data dalam penelitian ini menggunakan metode tes dan metode wawancara. Tes digunakan untuk mengetahui bentuk-bentuk miskonsepsi yang dilakukan siswa. Wawancara merupakan metode pengumpulan data yang menghendaki komunikasi langsung antara peneliti dan subjek atau responden (Arikunto, 2006: 149). Siswa yang menjadi subjek adalah siswa yang mengalami miskonsepsi terbanyak dalam tes yang dilakukan sebelumnya. Wawancara juga digunakan untuk meyakinkan peneliti akan kebenaran data yang diperoleh karena didapat langsung dari subjek yang diteliti.

Instrumen yang digunakan dalam penelitian ini dibagi menjadi 2 kategori, yaitu; instrumen utama dan instrumen pendukung. Instrumen utama dalam penelitian ini adalah peneliti sendiri. Menurut Moleong (2012: 168), "Kedudukan peneliti dalam penelitian kualitatif cukup rumit. Peneliti sekaligus merupakan perencana, pelaksana, pengumpulan data, analisis, penafsir data, dan pada akhirnya menjadi pelapor hasil penelitiannya". Menurut Moleong (2012: 169), berperan sebagai instrumen alat pengumpul data utama peneliti hendaknya mempunyai sifat-sifat sebagai berikut: “a) Responsif, b) dapat menyesuaikan diri, c) menekankan keutuhan, d) mendasarkan diri atas perluasan pengetahuan, e) memproses data secepatnya, f) memanfaatkan kesempatan untuk mengklarifikasikan dan mengikthisarkan, dan (g) memanfaatkan kesempatan untuk mencari respon yang tidak lazim dan idiosinkratik".

Instrumen Pendukung berupa lembar tes dan wawancara. Lembar tes dalam bentuk soal uraian operasi hitung campuran, merupakan salah satu instrumen pendukung yang akan digunakan untuk menganalisis miskonsepsi siswa. Bentuk tes uraian dipilih dalam penelitian ini karena untuk mengetahui alur berpikir dan tahapan pengerjaan yang dilakukan siswa dengan lebih jelas, sehingga dapat diketahui letak miskonsepsi yang dialami siswa untuk 
dilakukan analisis. Adapun langkah-langkah yang ditempuh untuk penyusunan butir soal adalah sebagai berikut: 1) mengidentifikasi materi yang diteliti berdasarkan kurikulum, 2) menyusun kisi-kisi butir soal tes, 3) membuat butir soal tes, 4) memvalidasi butir soal. Menurut Moleong (2012: 186), wawancara adalah percakapan dengan maksud tertentu. Lembar wawancara yang dimaksudkan disini berisi daftar pertanyaan atau indikator pertanyaan atau kisi-kisi pertanyaan yang mengarahkan pelaku wawancara, dalam hal ini peneliti, untuk mendapatkan data miskonsepsi siswa.

Prosedur pengolahan data untuk mengenali dan mendiskripsikan bentuk-bentuk miskonsepsi siswa dan penyebab siswa mengalami miskonsepsi terdiri dari: 1) menganalisis hasil tes dan wawancara yang telah dilakukan, serta 2) membuat tabulasi dan deskripsi data.

\section{Hasil Penelitian dan Pembahasan}

Hasil penelitian berikut merupakan rangkuman hasil tes dan wawancara dengan tigas subjek penelitian yaitu Akr, KRP dan PY. Berdasarkan hasil tes dan wawancara ditemukan lima jenis miskonsepsi dalam kognisi ketiga subjek tersebut, yaitu miskonsepi terjemahan, miskonsepsi konseptual, miskonsepsi strategi, miskonsepsi sistematis, miskonsepsi tanda, dan miskonsepsi mengoperasikan hitung campuran. Hutami (2018) dan Kefi, et al (2021) menyatakan bahwa miskonsepsi terjemahan, adalah kesalahan dalam memberi makna suatu ungkapan matematika atau kesalahan mengubah informasi ke ungkapan matematika. Miskonsepsi berhitung adalah kesalahan menghitung dalam operasi matematika seperti operasi penjumlahan, pengurangan, perkalian, dan pembagian. Miskonsepsi sistematik adalah kesalahan yang berkenaan dengan urutan pengerjaan atau ketidaksesuaian jawaban dengan penyelesaian. Miskonsepsi konsep adalah kesalahan memahami gagasan abstrak. Miskonsepsi strategi, adalah kesalahan siswa dalam memilih jalan yang tidak sesuai atau mengarah ke jalan buntu.

\section{Deskripsi hasil tes A}

\section{Soal nomor 1}

Subjek LPS melakukan semua bentuk miskonsepsi, sedangkan 3 subjek lainnya, yakni Akr., KRP, dan PY melakukan miskonsepsi konsep pada soal nomor 1 ini. Dilihat dari hasil kerja LPS pada soal ini, menunjukkan bahwa subjek belum menguasai materi prasyarat operasi hitung campuran, termasuk di dalamnya operasi hitung pengurangan yang melibatkan bilangan negatif, sehingga menjadi kendala serius pada materi operasi hitung campuran itu 
sendiri. Hasil penelitian yang sama, juga ditemukan dalam penelitian Fathahanik (2018) dan bahkan dialami oleh mahasiswa calon guru matematika, yang disebabkan miskonsepsi terhadap penggunaan garis bilangan dalam mengoperasikan pengurangan bilangan negatif.

\section{Soal nomor 2}

Subjek LPS melakukan semua bentuk miskonsepsi, sedangkan 3 subjek lainnya, yakni Akr., KRP, dan PY menjawab dengan benar pada soal ini, meskipun tanpa langkah-langkah, seperti yang diminta. Ketiga subjek ini dapat dikatakan telah memahami secara konsep operasi hitung campuran pada soal ini.

\section{Soal nomor 3}

Semua subjek melakukan semua bentuk miskonsepsi. Dilihat dari hasil kerja keempat subjek pada soal ini, menunjukkan bahwa semua subjek belum menguasai materi prasyarat operasi hitung campuran, sehingga menjadi kendala pada materi operasi hitung campuran itu sendiri. Materi prasyarat dalam belajar matematika berpengaruh terhadap keberhasilan belajar matematika. Hasil penelitian Putri, et al. (2014) menyatakan bahwa penguasaan materi prasyarat berpengaruh terhadap hasil belajar matematika. Relevan dengan hasil penelitian Munthazimah, et al (2021) bahwa penguasaan pengetahuan awal berkorelasi positif dengan kemampuan berpikir reflektif dalam belajar matematika.

\section{Soal nomor 4}

Semua subjek melakukan semua bentuk miskonsepsi. Dilihat dari hasil kerja keempat subjek pada soal ini, menunjukkan bahwa semua subjek belum menguasai materi prasyarat operasi hitung campuran, termasuk di dalamnya operasi hitung pembagian dan perkalian yang melibatkan bilangan negatif, sehingga menjadi kendala pada materi operasi hitung campuran itu sendiri.

\section{Soal nomor 5}

Tiga subjek, yakni LPS, KRP, dan PY melakukan semua bentuk miskonsepsi. Dilihat dari hasil kerja ketiga subjek pada soal ini, menunjukkan bahwa ketiganya belum menguasai materi prasyarat operasi hitung campuran, termasuk di dalamnya operasi hitung perkalian dan pembagian yang melibatkan bilangan negatif, sehingga menjadi kendala pada materi operasi hitung campuran itu sendiri. Sementara subjek Akr, tidak menjawab soal ini. 


\section{Deskripsi hasil tes B}

\section{Soal nomor 1}

Semua subjek melakukan miskonsepsi pada semua bentuk miskonsepsi. Dilihat dari hasil kerja keempat subjek pada soal ini, menunjukkan bahwa semua subjek tidak terbiasa diberikan soal cerita yang melibatkan hitung campuran. ditambah lagi penguasaan hitu dasarnya masih mengalami miskonsepsi pada semua bentuk miskonsepsi, sehingga menjadi kendalayang sangat berarti pada materi soal cerita yang melibatkan hitung campuran.

\section{Soal nomor 2}

Sama seperti pada soal nomor 1, semua subjek melakukan miskonsepsi pada semua bentuk miskonsepsi. Dilihat dari hasil kerja keempat subjek pada soal ini, menunjukkan bahwa semua subjek tidak terbiasa diberikan soal cerita yang melibatkan hitung campuran. ditambah lagi penguasaan hitu dasarnya masih mengalami miskonsepsi pada semua bentuk miskonsepsi, sehingga menjadi kendala yang sangat berarti pada materi soal cerita yang melibatkan hitung campuran.

Berikut ini hasil analisis dari miskonsepsi yang dialami siswa berdasarkan hasil tes dan wawancara subjek, yang dirangkum di atas. Berdasarkan hasil deskripsi data untuk soal A yang terdiri dari 5 soal tes, hanya 1 soal, yakni soal nomor 2 yang dikerjakan benar. Inipun hanya 3 yang benar dari 4 subjek dalam penelitian ini. Artinya, dapat dikatakan bahwa satu subyek ini sama sekali belum memahami materi operasi hitung campuran. Subjek LPS mengalami miskonsepsi pada seluruh soal A. Sementara 3 subjek lainnya mengalami miskonsepsi pada semua bentuk miskonsepsi 4 soal lainnya. Semua subjek, tidak mengerjakan soal sesuai perintah yang diberikan, yaitu "Jawablah soal matematika berikut dengan langkah-langkah yang lengkap, jelas dan tepat pada lembar jawaban yang disediakan". Meskipun ada jawaban benar, secara keseluruhan, subjek tidak mengerjakan soal dengan langkah-langkah seperti yang diminta (miskonsepsi terjemahan). Hasil penelitian ini juga ditemukan oleh Isyam, et al (2019) bahwa miskonsepsi terjemahan terjadi dalam memecahkan masalah terkait konsep aljabar.

Berdasarkan hasil deskripsi data pada soal B yang terdiri dari 2 soal tes, semua subjek tidak bias mengerjakan sama sekali. Akan tetapi setelah diwawancarai dan dibimbing melalui pertanyaan-pertanyaan yang mengarahkan siswa pada jawaban, maka 4 subjek ini dapat mulai mengerjakan. Berdasarkan pernyataan yang disampaikan subjek, jarang sekali 
diberikan soal jenis ini. Apabila dilihat dari hasil kerja subjek pada soal A, maka dapat dipastikan bahwa subjek akan mengalami semua bentuk miskonsepsi.

Berdasarkan pembahasan diatas, maka pertanyaan penelitian mengenai bentuk-bentuk miskonsepsi yang dialami siswa kelas V SDN 8 Pahandut Kota Palangka Raya pada materi hitung campuran telah terjawab. Dari hasil analisis ini pula dapat diketahui bahwa materi hitung campuran memang sangat memerlukan pemahaman konsep yang mendalam yang dapat diberikan oleh guru dalam pembelajaran. Hal ini sejalan dengan penelitian yang dilakukan oleh Setiawan (2015) mengenai adanya miskonsepsi yang dialami siswa serta faktor yang menyebabkan terjadinya miskonsepsi adalah faktor dari guru, siswa, dan teman.

\section{Kesimpulan}

Berdasarkan hasil penelitian dan pembahasan yang telah diuraikan di atas dapat disimpulkan sebagai berikut. Pertama, semua siswa peserta tes yang sekaligus menjadi subjek penelitian mengalami miskonsepsi terjemahan. Penyebab siswa mengalami miskonsepsi terjemahan pada soal A adalah kurang terbiasa dan terlatihnya siswa mengerjakan soal secara rinci berdasarkan langkah-langkah yang seharusnya dan benar menurut kaidah operasi hitung campuran. Sementara pada soal B, miskonsepsi terjemahan terjadi adalah kurangnya siswa dalam memahami soal dalam bentuk cerita, dan kemudian mengubahnya menjadi bahasa matematika yang benar. Lebih lanjut, hal ini disebakan karena siswa tidak terbiasa mendapatkan jenis soal ini. Kedua, terjadi miskonsepsi konsep mencapai $75 \%$ subjek (3 orang), hanya dapat mengerjakan benar $20 \%$ soal jenis A (1 dari 5 soal). Penyebab siswa mengalami miskonsepsi konsep adalah siswa tidak memahami konsep atau definisi operasi hitung campuran, lebih spesifik siswa tidak memahami konsep atau definisi operasi hitung dengan benar. Sementara pada soal B, miskonsepsi konsep terjadi adalah kurangnya siswa dalam memahami soal dalam bentuk cerita, dan kemudian mengubahnya menjadi bahasa matematika yang benar. Lebih lanjut, hal ini disebakan karena siswa tidak terbiasa mendapatkan jenis soal ini. Ketiga, semua siswa juga mengalami miskonsepsi strategi. Meskipun variasi jawaban siswa sangat beragam, akan tetapi siswa yang mengalami miskonsepsi strategi, bentuk miskonsepsinya sama. Penyebabnya adalah siswa kurang terampil dan masih kebingungan dalam menggunakan dan menentukan prosedur, serta sifat operasi hitung dengan tepat. Konkritnya siswa masih lemah dalam operasi pengurangan bilangan negative. Keempat, semua siswa mengalami miskonsepsi sistematik. Penyebabnya 
adalah pemahaman siswa yang kurang dalam penulisan sistematika penyelesaian yang benar. Kurang lengkap dan tepat dalam menuliskan langkah-langkah untuk menyelesaikan soal, siswa tidak menuliskan secara terperinci, sistematis dan benar. Kelima, ada siswa yang mengalami miskonsepsi tanda yaitu siswa yang tidak tahu cara operasi hitung mana yang harus dikerjakan terlebih dulu. Penyebab siswa mengalami miskonsepsi tanda adalah siswa lupa serta kurang teliti dan juga dapat dikaitkan dengan miskonsepsi yang lain. Konkritnya siswa masih lemah dalam operasi pengurangan bilangan negatif, Hasil penelitian ini relevan dengan hasil penelitian Sumarna (2020), siswa kelas IV Sekolah Dasar salah tanda positif dan negatif dalam menentukan operasi hitung penjumlahan dan pengurangan dua bilangan bulat berlawanan tanda dan bertanda sama dan salah hasil akhir operasi hitung yang dilakukan. Keenam, terjadinya miskonsepsi berhitung yang disebabkan karena siswa melakukan kesalahan dalam melakukan operasi hitung campuran meskipun ada yang menyatakan terburu-buru dalam mengerjakan. Menurut Sumarna (2020) miskonsepsi berhitung disebabkan siswa tidak memiliki pemahaman yang utuh terkait operasi hitung bilangan bulat.

Sementara secara umum faktor penyebab terjadinya miskonsepsi siswa pada materi operasi hitung campuran meliputi rendahnya kemampuan siswa terhadap materi operasi hitung dasar secara umum, kurang teliti dalam membaca perintah soal dan melakukan perhitungan, kurangnya latihan soal dan pengalaman belajar. Siswa kesulitan dalam menentukan operasi apa saja yang digunakan dalam menyelesaikan soal, khususnya soal dalam bentuk cerita. Kurangnya minat belajar siswa terhadap mata pelajaran matematika, perasaan kurang senang terhadap matematika yang mengakibatkan rendahnya motivasi dalam belajar matematika, serta perasaan takut dan malu bertanya pada guru apabila siswa masih belum paham dengan materi yang dipelajari, menjadi salah satu penyebab yang dapat diduga menjadi penyebab terjadinya miskonsepsi.

\section{Daftar Pustaka}

Arikunto, S. 2006. Prosedur Penelitian Suatu Pendekatan Praktik. Jakarta: PT Rineka Cipta.

Fatmahanik, U. 2018. Penelusuran miskonsepsi operasi bilangan bulat dalam pembelajaran matematika pada mahasiswa PGMI dengan menggunakan CRI (Certainty of Respons Index). Cendikia 16(1), 167-187.

Hamalik, O. 2014. Perencanaan Pengajaran Berdasarkan Pendekatan Sistem. Jakarta: PT Bumi Aksara. 
Herutomo, R.A. dan Saputro, T.E.M. 2014. Analisis Kesalahan dan Miskonsepsi Siswa Kelas VIII Pada Materi Aljabar. Diunduh pada tanggal 17 maret 2017, darihttp://ejournal.sps.upi.edu/index.php/edusentris/article/viewFile/140/110.

Hutami, D.P.N. Analisis Miskonsepsi Siswa dalam Menyelesaikan Soal Barisan dan Deret berdasarkan Certainty of Response Index (CRI) ditinjau dari Gaya Kognitif Reflektif dan Impulsif. Skripsi. Jember: Universitas Negeri Jember. https://repository.unej.ac.id/handle/123456789/86491.

Isyam, Y.A.N. Susanto, Oktaningtyas, E. (2019). Identifikasi miskonsepsi siswa dalam menyelesaikan soal TIMSS konten aljabar ditinjau dari kecemasan matematika. Kadikma, 10(1), 74-84.

Kefi, M.E., Disnawati, H. \& Suddin, S. 2021. Analisis Kesulitan Siswa dalam Menyelesaikan Soal Relasi Menggunakan Certainty of Resonse Index (CRI). JUPITEK: Jurnal Pendidikan Matematika, 4(1), 21-26. DOI https://doi.org/10.30598/jupitekvol4iss1pp21-26.

Kesumawati, N. 2008. Pemahaman Konsep Matematik dalam Pembelajaran Matematika. Diunduh pada tanggal 23 Oktober 2017, darihttps://digilib.uns.ac.id

Lestari, E. 2017. Analisis Miskonsepsi Siswa Pada Materi Aritmatika Sosial Siswa Kelas VII SMP Negeri 4 Jember. Diunduh pada tanggal 25 September 2017 dari, http://repository.unej.ac.id

Munthazhimah, M., Turmudi, T. \& Prabawanto, S. 2019. The relation between prior knowledge and students' mathematics reflective thinking ability. Proceeding og Mathematics and Science Internationa Seminar (MASEIS), pp.1-6. doi:10.1088/1742-6596/1731/1/012043.

Moleong, L.J. 2012. Metodologi Penelitian Kualitatif. Bandung: PT Remaja Rosda Karya.

Putri, A.P., Nursalam \& Sulastri, E. 2014. Pengaruh penguasaan materi prasyarat terhadap hasil belajar matematika siswa kelas VIII SMPN Sinjai Timur. Jurnal Matematika dan Pembelajaran (MaPan), 2(1), 17-30.

Sardiman, A.M. 2014. Interaksi dan Motivasi Belajar Mengajar. Depok: PT Rajagrafindo Persada.

Setiawan, M.I. 2015._Analisis Miskonsepsi Siswa dan Faktor Penyebabnya Pada Pokok Bahasan Sistem Persamaan Linear Dua Variabel (SPLDV) di Sekolah Menengah Pertama Negeri 2 Sidoarjo. Diunduh pada tanggal 7 november 2017, darihttp://digilib.uinsby.ac.id/id/eprint/3825.

Suparno, P. 2013. Miskonsepsi dan Perubahan Konsep dalam Pendidikan Fisika. Jakarta: PT Grasindo.

Sumarna, N. 2020. Identifikasi Miskonsepsi Siswa dengan Certainty of Response Index (CRI) Mengenai Konsep Bilangan Bulat di Kelas IVC SDN 7 Kendari Barat. Jurnal Ilmiah Pembelajaran Sekolah Dasar, 2(1), 85-93. 